\title{
Stability of spatial structures of demersal assemblages: a multitable approach
}

\author{
Jean-Claude Gaertner ${ }^{\left(1^{*}\right)}$, Daniel Chessel ${ }^{(2)}$, Jacques Bertrand ${ }^{(3)}$ \\ (1) IFREMER, Laboratoire d'Ecologie halieutique, 1 me Jean Vilar, BP 171, 34203 Sète cedex, France. \\ (2) Laboratoire d'Ecologie des eaux douces et des grands fleuves, URA CNRS 1451, Université Lyon 1, \\ 69622 Villeurbanne cedex, France.
}

(3) IFREMER, Laboratoire Ressources halieutiques, 1 nue Jean Vilar, BP 171, 34203 Sète cedex, France.

Received October 10, 1997; accepted February 16, 1998

\begin{abstract}
The present work is based on a set of bottom trawl surveys performed in the Gulf of Lions between 1983 and 1992. A new method which couples the STATIS multitable approach with the logic of correspondence analysis (CoA) is proposed to study the stability of spatial organization of demersal assemblages in terms of species composition. This CoA version of STATIS has provided a clear representation of the stable part of the spatial structure of the assemblages. In addition, it gave an insight into the interannual variations of the distribution of each population around the reference structure. Our results showed that the demersal assemblages of the Gulf of Lions exhibited strong spatial structuring, mainly orientated along a bathymetric gradient. This gradient is structured around three major regions: the coast, the continental shelf and the continental slope. Despite sampling variations that occurred during the course of the study, the analysis showed a high degree of reproducibility for this spatial pattern. With the exception of Mullus surmuletus, the species considered in this investigation exhibit limited variations in their spatial distribution. Finally, in the absence of $\log$-books covering the activities of commercial fishing vessels, these findings constitute a base of reference for the analysis of the dynamics of fishing fleets exploiting the demersal resources of the Gulf of Lions. (C) Ifremer-Elsevier, Paris
\end{abstract}

Fish assemblage / trawl surveys / multitable analysis / correspondence analysis / Mediterranean sea / stability / spatial structure

Résumé - Stabilité de la structuration spatiale des assemblages démersaux: une approche multitableau. Ce travail porte sur une série de campagnes de chalutage de fond réalisé dans le golfe du Lion entre 1983 et 1992. Une nouvelle méthode fondée sur le couplage de la technique multitableaux STATIS et de l'analyse factorielle des correspondances (AFC) est proposée afin d'étudier l'organisation spatio-temporelle des assemblages démersaux, poissons et quelques céphalopodes, en terme de composition spécifique. Cette version AFC de STATIS a fourni une représentation claire de la part stable de l'organisation spatiale des assemblages. De plus, elle nous a permis d'appréhender les variations interannuelles de la distribution de chaque population autour de la structure de référence. Nos résultats montrent que les assemblages démersaux du golfe du Lion présentent une forte structuration spatiale, principalement orientée selon un gradient bathymétrique. Ce dernier est structuré en trois grandes régions: la côte, le plateau continental et le talus continental. En dépit des variations d'échantillonnage survenues au cours de la période d'étude, l'analyse a mis en évidence une forte reproductibilité de ce schéma d'organisation. A l'exception de Mullus surmuletus, les espèces considérées dans ce travail présentent des variations limitées de leur distribution spatiale. Enfin, en l'absence de livres de bord sur l'activité des navires professionnels, ces résultats constituent une base de référence pour l'analyse de la dynamique des flottilles exploitant les ressources démersales dans le golfe du Lion. () Ifremer-Elsevier, Paris

Assemblage de poissons / chalutage / analyse multitableaux / Méditerranée / stabilité / structure spatiale

\section{INTRODUCTION}

In fishery ecology, numerous approaches aimed at providing backup for the management of multispecies resources are based on the identification of species assemblages in space and the analysis of their persistence in time $[4,17,18,19,30,35,49,51]$. The monitoring over time of the spatial organization patterns of assemblages plays an important role in the estimation of the reaction of communities to disturbances to 
which they may be exposed $[37,39]$. In addition, it provides basic knowledge for assessing and reducing by-catches $[30,35]$, one of the main objectives in fishery management [16].

From the methodological point of view, studies on this theme require the acquisition of data on wide ranges of species that are not limited to commercially exploited resources alone $[10,51]$. Thus most studies that analyse the spatial and temporal dynamics of demersal resources are based on experimental surveys repeated at more or less regular intervals during a specific period of the year $[11,17-19,21,28,30,34$, 51]. The result is the acquisition for each survey of a table of the species density sampled at the different stations. The study of the stability of multispecies spatial structures requires the combined analysis of all the different tables. Each of the two most commonly used approaches for this purpose is based on classification methods or simple factorial analyses.

The first approach involves the comparative reading of the typologies obtained separately for each of the tables of data. It consists in roughly estimating the graphic similaritics between the structures observed independently for each survey $[17-19,30,36,40]$. However, this procedure soon runs into difficulties whenever the tables are too numerous or extensive [2]. The second approach involves carrying out multivariate analysis after pooling on a single table the data from different surveys. This method, used for the analysis of the organization of demersal fishes by Mahon in Nova Scotia [29], by Roel on the west coast of South Africa [42], by Wantiez in Nouvelle-Calédonie [50] and by Weinberg on the west coast of the United States [51], can however result in a confusing mixture of spatial and temporal effects [8].

In this context, we needed a method capable of coordinating the analyses of each survey within a rigourous and reproducible framework, and providing a clear representation of the stable and unstable parts of the spatial organization of the assemblages of species. Multitable factorial analyses $[9,12,26,27$, etc. $]$ represent an approach that may well meet these requirements. Although they are still little used in fishery sciences and ecology, these methods can offer a theoretical framework suited to investigation of the reproducibility of multivariate structures [8].

Given the multispecies feature of the demersal fishery of the Gulf of Lions, we have focused on the stability of the spatial structures in terms of species composition. In the present study, we propose a new method that couples the STATIS multitable approach [27] with the logic of correspondence analysis ( $\mathrm{CoA})$ $[3,25]$. This work is based on the results of a series of experimental trawl surveys carried out in the Gulf of Lions by the Fishery Resources laboratory of IFREMER-Sète. Our aim is to obtain an accurate representation of (i) the stable part of the spatial structure of assemblages of demersal species, (ii) the role of each survey in the construction of this common structure, and (iii) the variations over time of each of the species around this structure.

\section{MATERIAL AND METHODS}

\subsection{Data type and origin}

The present work was performed by using a set of abundance indices collected in the Gulf of Lions (figure 1). Previous studies pointed out, for most of the groundfishes considered, the absence of seasonal variability of their spatial distribution [20]. Thus, in our study we worked on six bottom trawl surveys conducted yearly at the same period (June) between 1983 and 1992.

A stratified random sampling design was used, based on depth and geographical zones. Locations of sample units were selected randomly within each stratum before each survey. A bottom trawl (Le Drezen $20 \mathrm{PM}$ ) with a vertical opening of less than $1.8 \mathrm{~m} \mathrm{[7]}$ was used. Tows were about $30 \mathrm{~min}$ in duration when the depth was between 10 and $150 \mathrm{~m}$, and $60 \mathrm{~min}$ when deeper (from 150 to $500 \mathrm{~m}$ ). The main variations in sampling design that occured during the course of the study are given in table $I$.

The hauls included 113 swimming species (groundfishes and a few cephalopods), but only 45 species (table $I I$ ) were sufficiently abundant to be included in the analysis (i.e. they were present in more than $5 \%$ of the tows). For each tow, the densities in number of individuals were expressed for a same surface unit (ha). The data were log-transformed before conducting the analysis to minimise the dominant effect of exceptional catches.

\subsection{Methods}

First, a between-class correspondence analysis was used to test the existence of a significant part of varia-

Table I. Sampling characteristics that have been changed during the course of the study. SRS = Stratified Random Sampling, RS $=$ Regular Sampling.

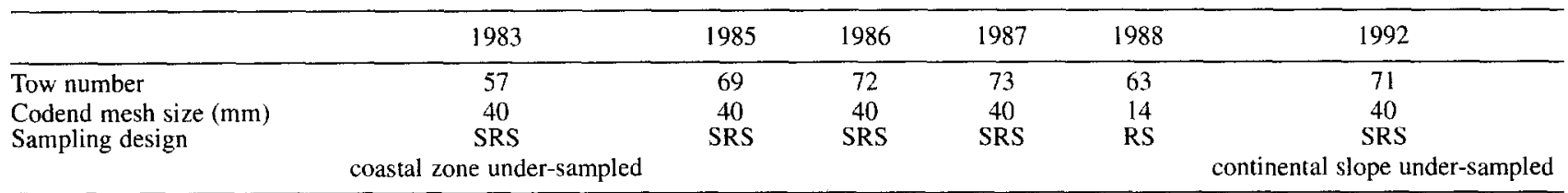




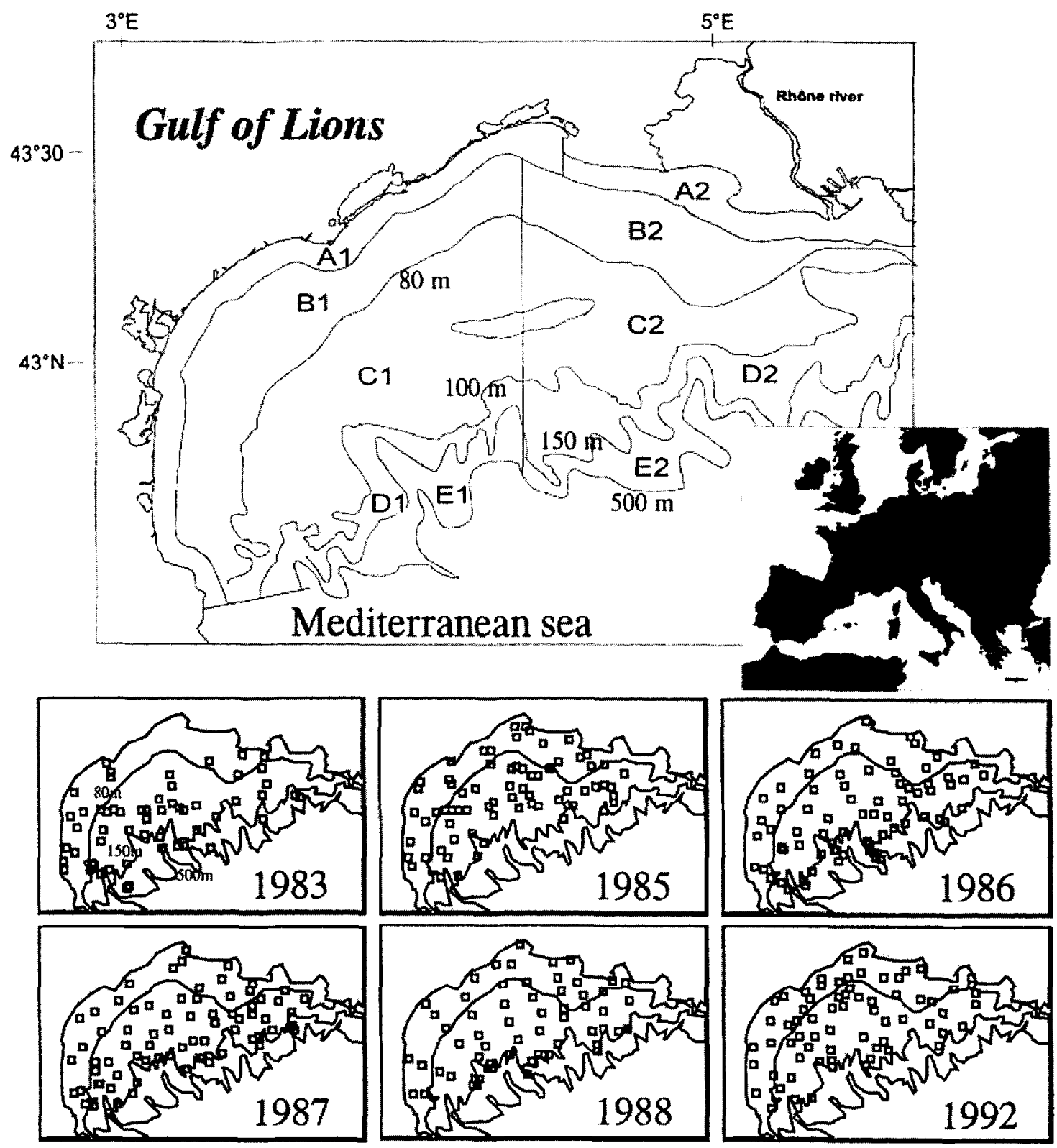

Figure 1. Localization of the study site: the Gulf of Lions. Spatial distribution of the sampled stations for each bottom trawl survey. Bathymetry and strata used in the sampling design. $A=$ from the coast to the 3 nautic miles; $B=$ from the 3 nautical miles to $80 \mathrm{~m}$. depth; $\mathrm{C}=$ from the $80 \mathrm{~m}$ to 100 $\mathrm{m}$. depth; $\mathrm{D}=$ from the $100 \mathrm{~m}$ to $150 \mathrm{~m}$. depth; $\mathrm{E}=$ from the $150 \mathrm{~m}$ to $500 \mathrm{~m}$ depth; 1 - western zone; 2 - eastern zone.

bility in the overall species composition between the different surveys. This analysis consisted of analysing the table of total numbers of specimens per survey and by species (matrice crossing 6 periods and 45 species). A second step involved the projection of the different stations as supplementary rows. Thus, the inter-period CoA does not operate on the spatial structuring of the assemblages of species, but on the mean differences of the species composition between the surveys, at the Gulf of Lions scale. A permutation test, which extends the test of Romeshurg [43] to all variables [see 31], is carried out to test the significance of the inter-period variability.

Next, a new variant of the STATIS multitable method was used to describe the stable part and the variable part of the spatial structuring of the assemblages. The underlying theoretical basis of STATIS is described by Escoufier [13, 14] and Robert and Escoufier [41]. The classical version of STATIS [27] is based on the logic of Principal Component Analysis (PCA) [23]. However, the analysis at a given date of the spatial organization of the assemblages in terms of 
Table II. List of the species considered with detail on the abbreviated names used: bony fish, shark, ray, skate and cephalopod.

\begin{tabular}{|c|c|c|}
\hline Label & Species & Family \\
\hline ARGE & Argentina sphyraena Linnaeus, 1758 & Argentinidae \\
\hline ARNL & Arnoglossus laterna (Walbaum, 1792) & Bothidae \\
\hline ARNT & Arnoglossus thori Kyle, 1913 & Bothidae \\
\hline ASPC & Aspitrigla cuculus (Linnaeus, 1758) & Triglidae \\
\hline ASPO & Aspitrigla obscura (Linnaeus, 1764 ) & Triglidae \\
\hline BLEN & Blennius ocellaris Linnaeus, 1758 & Blennidae \\
\hline BOOP & Boops boops (Linnaeus, 1758) & Sparidae \\
\hline BUGL & Buglossidium luteum (Risso, 1810) & Soleidae \\
\hline CAPO & Capros aper (Linnaeus, 1758) & Caproidae \\
\hline CEPO & Cepola rubescens Linnaeus, 1766 & Cepolidae \\
\hline $\mathrm{CITH}$ & Citharus linguatula (Linnaeus, 1758) & Citharidae \\
\hline CONG & Conger conger (Linnaeus, 1758) & Congridae \\
\hline EUTR & Eutrigla gurnardus (Linnaeus, 1758) & Triglidae \\
\hline GALU & Galeus melastomus Rafinesque, 1810 & Scyliorhinidae \\
\hline LEPM & Lepidorhombus boscii (Risso, 1810) & Bothidae \\
\hline LEPC & Lepidotrigla cavillone (Lacepède, 1801) & Triglidae \\
\hline LEPD & Lepidotrigla dieuzeidei Audoin, in Blane and Hureau, 1973 & Triglidae \\
\hline LOPB & Lophius budegassa Spinola, 1807 & Lophiidae \\
\hline LOPP & Lophius piscatorius Linnaeus, 1758 & Lophiidae \\
\hline MACO & Macroramphosus scolopax (Linnaeus, 1758) & Macroramphosidae \\
\hline MERL & Merluccius merluccius (Linnaeus, 1758) & Merluciidae \\
\hline MICU & Microchirus variegatus (Donovan, 1808) & Soleidae \\
\hline MULB & Mullus barbatus Linnaeus, 1758 & Mullidae \\
\hline MULS & Mullus surmuletus Linnaeus, 1758 & Mullidae \\
\hline PAGA & Pagellus acarne (Risso, 1826) & Sparidae \\
\hline PAGY & Pagellus erythrinus (Linnaeus, 1758) & Sparidae \\
\hline PHYL & Phycis blennoides (Brünnich, 1768) & Gadidae \\
\hline RAJA & Raja clavata Linnaeus, 1758 & Rajidae \\
\hline SCOL & Scorpaena loppei Cadenat, 1943 & Scorpaenidae \\
\hline SCON & Scorpaena notata Rafinesque, 1810 & Scorpaenidae \\
\hline SCYO & Scyliorhinus canicula (Linnaeus, 1758) & Scyliorhinidae \\
\hline SERC & Serranus cabrilla (Linnaeus, 1758) & Serranidae \\
\hline SERH & Serranus hepatus (Linnaeus, 1758) & Serranidae \\
\hline SOLE & Solea vulgaris Quensel, 1806 & Soleidae \\
\hline SQUA & Squalus acanthias Linnaeus, 1758 & Squalidae \\
\hline TORP & Torpedo marmorata Risso, 1810 & Torpedinidae \\
\hline TRAH & Trachinus draco Linnaeus, 1758 & Trachinidae \\
\hline TRIY & Trigla lyra Linnaeus, 1758 & Triglidae \\
\hline TRIP & Trigloporus lastoviza (Brünnich, 1768) & Triglidae \\
\hline TRIS & Trisopterus minutus capelanus Lacepede, 1800 & Gadidae \\
\hline URAN & Uranoscopus scaber Linnaeus, 1758 & Uranoscopidae \\
\hline ZEUS & Zeus faber Linnaeus, 1758 & Zeidae \\
\hline ELED & Eledone moschata (Lamarck, 1798) & Octopodidae \\
\hline LOLI & Loligo vulgaris Lamarck, 1798 & Loliginidae \\
\hline SEPO & Sepia orbignyana de Ferussac, 1826 & Sepiidae \\
\hline
\end{tabular}

species composition is technically feasible using CoA [45-47]. The study of the stability of the spatial organization therefore required the development of a $\mathrm{CoA}$ version of STATIS. This enabled us to exploit the properties of multitable analyses (analysis of stability) while conserving the logic of $\mathrm{CoA}$ (description of multispecies spatial structures).

The general functioning principle of STATIS is schematised in figure 2. In the present case, (i.e. measurement of the same 45 spccics in 6 groups of stations) the first stage of the CoA version of STATIS consists of calculating a matrix of scalar products between species for each survey. This stage is carried out in order to standardize the dimensions of tables and allow comparison by calculation of a matrix of intermatrix scalar products (i.e. between surveys).
The diagonalization of this matrix is carried out. The $k$ coefficients of the first eigenvector are then used to weight the $k$ matrices of scalar product between species with the aim of constructing a mean table of maximum inertia (compromise table). Thus, in the construction of the compromise table a greater importance is given to tables which have similar structures and lesser importance to the other tables. The analysis (CoA) of the compromise table define axes and components which express the stable part of the structures studied (spatial structures in the present case). In addition, the projection of the $\mathrm{k}$ matrices onto the compromise allow us to draw the trajectories that represent the temporal variations of each species around the common structure. Technically, this involves projecting the 


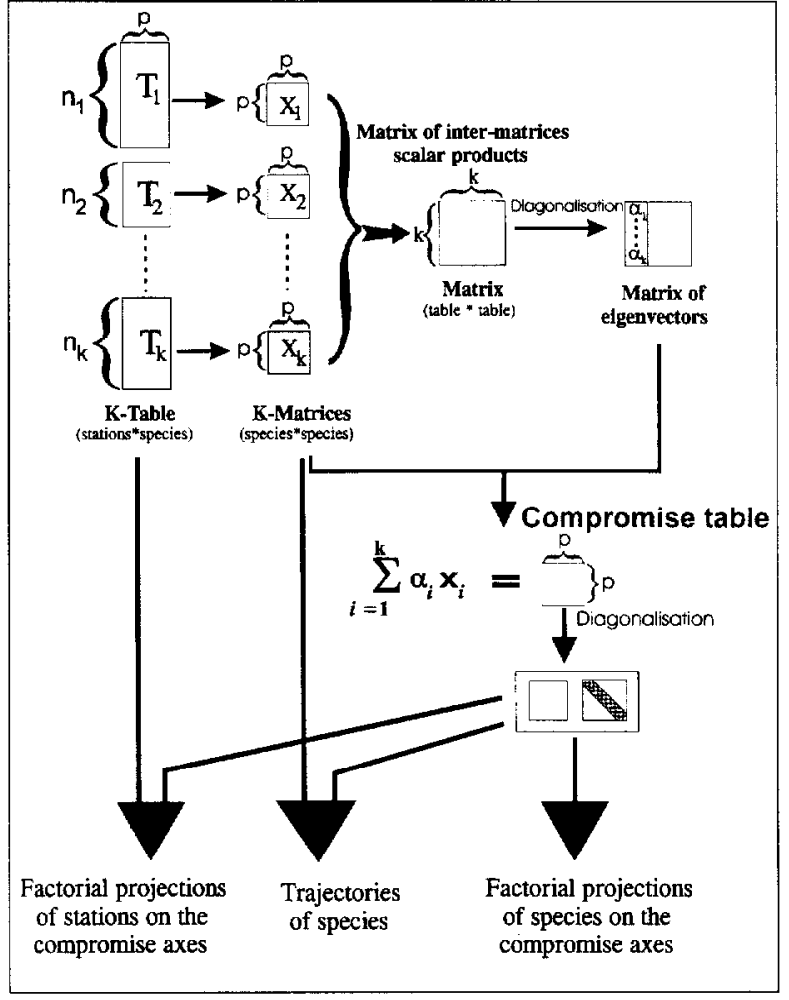

Figure 2. Simplified scheme of the principle of the STATIS method. For the survey $i$ : $\mathrm{T}_{i}=$ initial table; $\mathrm{p}=$ number of species; $\mathrm{n}_{i}=$ number of stations sampled; $X_{i}=$ matrix of scalar products between species; $\alpha_{i}=$ coefficients of the first eigenvector.

factorial scores that each species obtains in each of the tables onto the axes of the compromise table.

In comparison with the classical version of STATIS [27], the variant proposed in the present study needs several transformations of the initial tables which are provided in the Appendix. This CoA version of STATIS may currently be performed with the ADE-4 software [48]. This software, the tables of data used in this work, the details of the various steps of the calculations and the complete results are freely available at thc following address: http://biomserve.univ-lyon 1.fr/ ADE-4.html

\section{RESULTS}

The inter-period CoA followed by a permutation test ( 1000 permutations) has demonstrated the occurrence of significant temporal variations $(P<0.05)$ in overall species composition (i.c. all stations taken together). This instability over time, induced by the years 1988 and 1992 (figure 3), complicates the analysis of the stable part of the organization of communities during the period of study. In this context, the co-ordination of the analyses by means of a multitable method was therefore necessary.

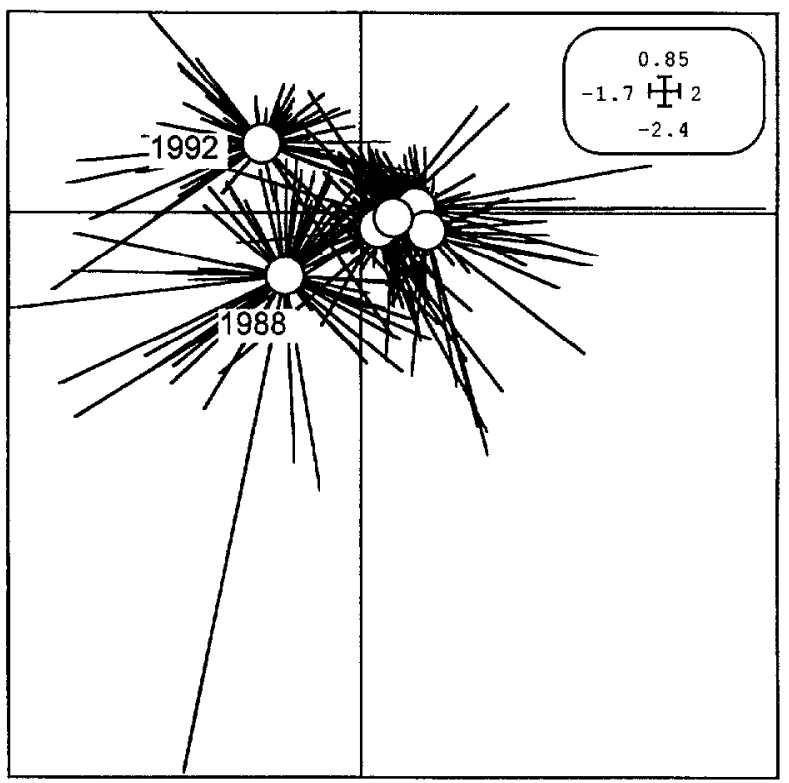

Figure 3. Projection of the surveys on the first factorial plane of the betwecn-class correspondenec analysis. The projection of each station is related to the corresponding trawl survey.

The use of STATIS shows that the contribution of the different surveys to the construction of the compromise table are well balanced (weighting: 0.39 to 0.42 ). None of the surveys was therefore either favoured or ignored in the constitution of the STATIS compromise table. In addition, the fit of each of the tables to the compromise table is relatively constant (table $I I I$ ). The strongest values are obtained for the surveys between 1985 and 1988. The weakest values - observed for 1983 and 1992 - indicate that the structure of these two surveys is less well taken into account in the compromise table. In short, one should find in the analysis of each table a common part and a specific part.

Table III. Description of the structure defined for each survey. Stations : number of sampled stations. Weight: contribution of each table in the construction of the compromise. $\operatorname{Cos}^{2}$ : fit of each table to the compromise.

\begin{tabular}{lccc}
\hline Survey & Stations & Weight & $\operatorname{Cos}^{2}$ \\
\hline 1983 & 55 & 0.39 & 0.41 \\
1985 & 69 & 0.41 & 0.48 \\
1986 & 72 & 0.43 & 0.49 \\
1987 & 73 & 0.42 & 0.48 \\
1988 & 61 & 0.40 & 0.50 \\
1992 & 69 & 0.37 & 0.30 \\
\hline
\end{tabular}

The similarity between the projections of the first and the second axes of the separate CoAs of 1985 , 1986, 1987 and 1988 with the first two axes of the compromise table confirms the very good fit of these surveys with the compromise (figure 4). The fit with the compromise of the first two axes of the separate 


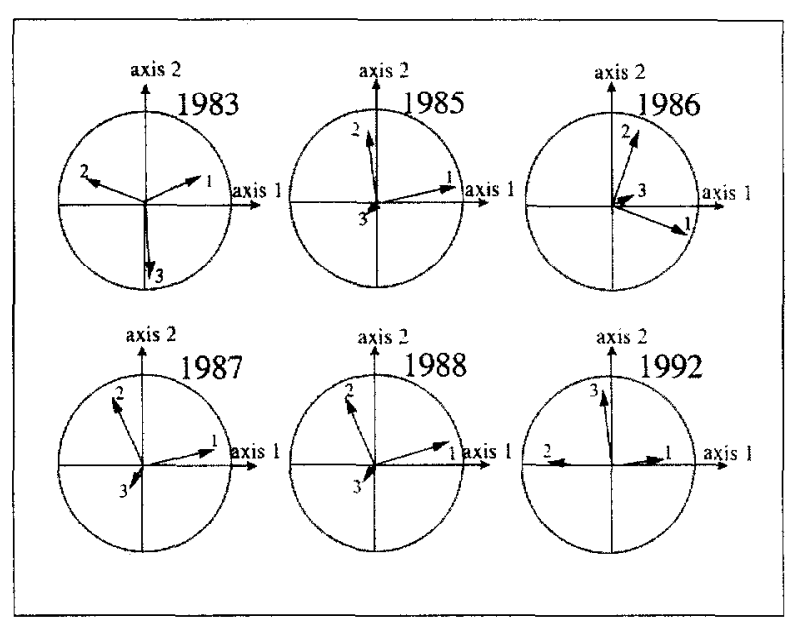

Figure 4. Projection of the factorial axes of the separate correspondence analysis of each survey (arrows) on the two first factorial axes of the STATIS compromise.

CoAs of 1983 and 1992 is less good. The first plane of the compromise nevertheless provides a good summary of the three main organizational directions of each of these two surveys. Thus, despite a few limited variations, a good degree of reproducibility of the spatial organization of the assemblages over the whole of the study period is apparent.

The stable part of the main organizational directions of the assemblages of species shows a pattern of organization based on a coast-open sea gradient (figure 5 a) which can be divided into three regions: the coast, the continental shelf and the continental slope (figure $5 \mathrm{~b}$ ). In contrast to the strong homogeneity of the continental shelf, the coastal region and the upper part of the continental slope are marked by strong heterogeneity.

The correspondence with the species (figure 6) allows the identification of the taxa responsible for these gradients. It provides a typology of species on the basis of the structure common to the different surveys. Of note too is the contrast between the group of coastal species (Buglossidium luteum, Aspitrigla obscura, Arnoglossus thori, etc.) and that of the slope species (Galeus melastomus, Macroramphosus scolopax, Phycis blennoides, Trigla lyra, etc.). The transition between these two groups occurs through the species with an intermediate distribution on the gradient (Solea vulgaris, Torpedo marmorata, Conger conger, Serranus hepatus, Citharus linguatula, Lepidorhombus boscii, etc.). Finally, the representation of the trajectories enables us to move on from analysis of the common structure to analysis of stability of the position of the taxa, corresponding to the stability of the spatial structure (figure 7). The sometimes wide deviations between the different trajectories of Buglossidium luteum on the coast or Galeus melastomus on the slope point out certain fluctuations in the distribution of these two species. Nevertheless, their constant

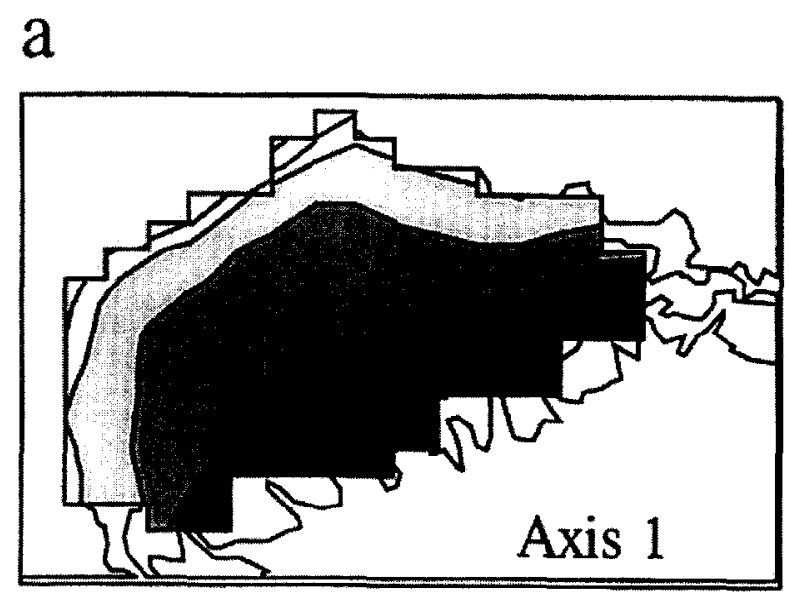

b

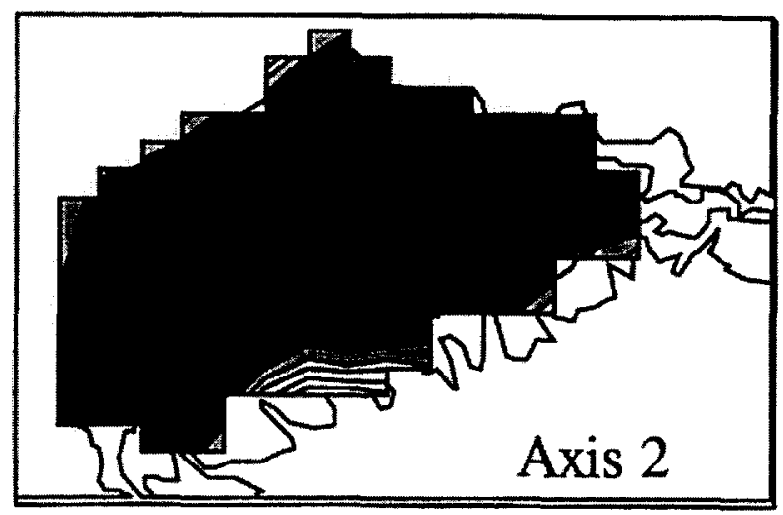

Figure 5. Map of the stable structure (according to the stations). Map of the factorial scores of the whole of the stations on the two first factorial axes of the STATIS compromise.

position at the two ends of the gradient shows that these variations were strictly limited to within their native region. Their position in relation to other species remains very stable.

In contrast, a species of red mullet (Mullus surmuletus) is characterised by very strong variability in relation to its reference position. Although its projection outside the gradient (inside the parabola) is rather characteristic of an ubiquitous species, the maps of the abundance by survey (figure 7) shows that it is in fact a species caught successively in several regions of the Gulf of Lions. In addition, the whole of the population sampled is affected by these variations, which therefore do not result from a phenomenon of migration dependent on the age of individuals.

The strong overlap of the ranges of distribution observed on the continental shelf complicates the ana- 


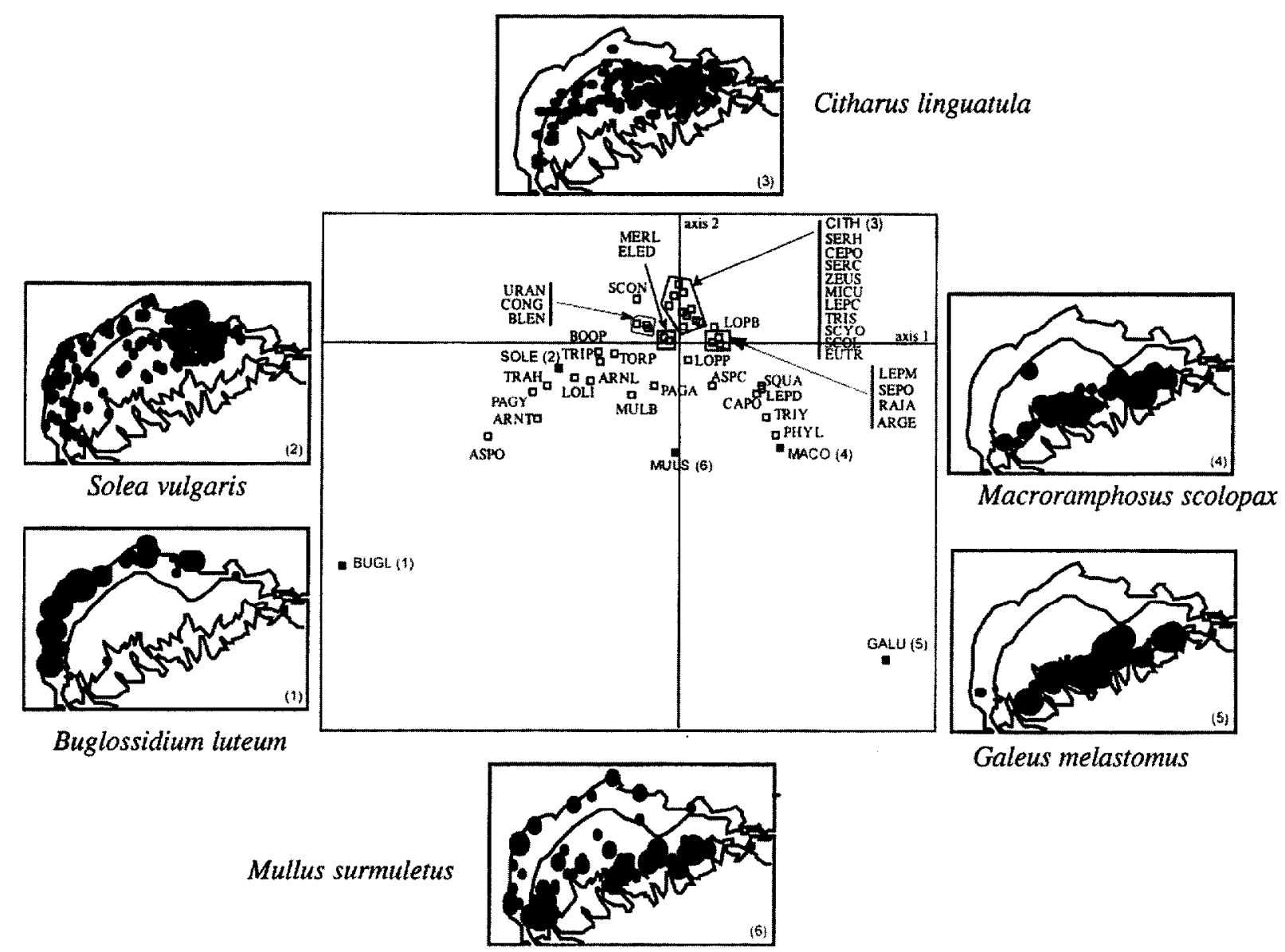

Figure 6. Map of the stable structure (according to the species). Projection of the species on the first factorial plane of STATIS compromise. The map of the abundance, for all the surveys, of some characteristic species is presented.

lysis of the trajectories of species colonising this region. In consequence, the projection of only few representative species is provided to illustrate the temporal variations of the species of this region (figure 8). A generally weak variation of species (Aspitrigla obscura, Solea vulgaris, Scorpaena notata, Citharus linguatula, Aspitrigla cuculus, etc.) around their reference position may be observed, which indicates a strong degree of reproducibility of interspecies associations.

\section{DISCUSSION}

In the present study, the inter-period CoA has revealed a significant part of the temporal variability of the overall species composition of demersal assemblages (i.e. at the scale of the Gulf of Lions). Thus, in our case the use of a multivariate analysis after regrouping on a single table the data from the different surveys, carried out on similar species in the Tyrrhenian Sea [4], would therefore not have been appro- priate. In contrast, the CoA version of STATIS enabled us to obtain a detailed and accurate view of (i) the stable part of the spatial organization of the demersal assemblages of the Gulf of Lions and (ii) of the variations of each species around this common structurc.

The analysis of the respective contribution and the fit of each survey with the compromise table has evidenced a strong degree of reproducibility of the spatial pattern of the assemblages. As a general rule, if a table within a particular set has a very specific structure, it will be less considered in the compromise. So, it is possible to keep this table in the analysis without strongly affecting the description of the common structure. Moreover, in this kind of situation, the study of the trajectories will allow the identification of species concerned by the variations in the assemblage structure. In our study, only the 1983 and 1992 surveys give a little less good fit with the STATIS compromise table. The explanation for this phenomenon, which appear of limited importance, may lie in the undersampling of a large part of the coast in 1983 and of the continental slope in 1992. On the other hand, despite a 


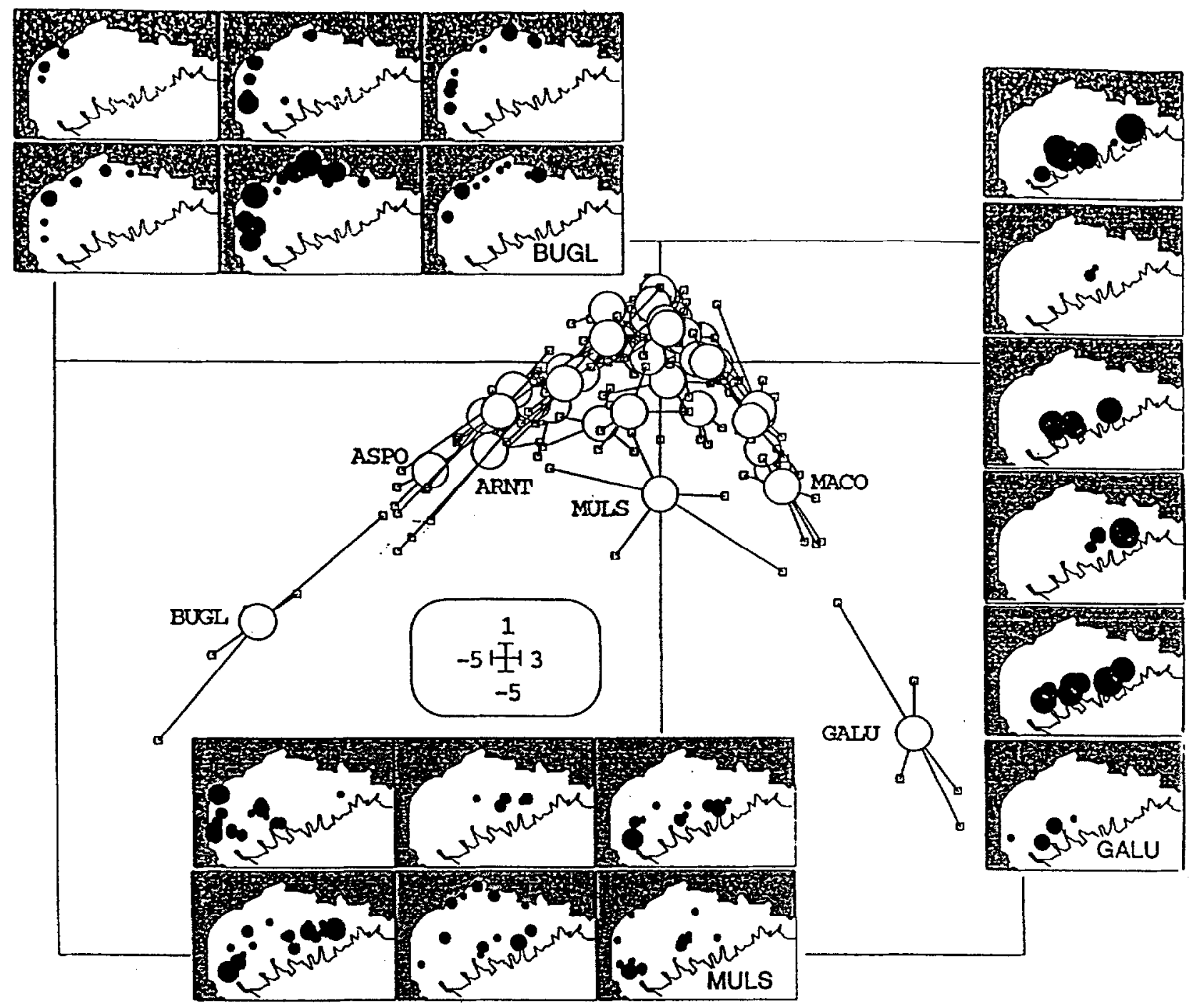

Figure 7. Variability of the species around the stable structure. Projection of the trajectories on the first factorial plane of STATIS compromise. The position of a species in each survey (D) is related to its position in the compromise (O). The map, for each survey, of the abundance of some characteristic species is presented.

reduction in the mesh size of the trawl net and an alteration in the sampling strategy, the 1988 survey gives a good fit with the compromise. In short, our perception of the spatial organization of the demersal assemblages in the Gulf of Lions has not been significantly affected by variations in sampling.

The stable part of the spatial organization takes the form of a bathymetric gradient, structured on three major regions: the coast, the continental shelf and the continental slope. The organization of demersal fish species according to depth is a phenomenon that is often observed throughout the world's oceans $[6,17$, $21,24,30,32,42]$. Similarly, the persistence of this pattern of organization over time has often been described $[11,18,21,30,36]$.
The definition of regions that are stable in species composition constitutes an indirect source of information on the organization of the fleet concerned [51]. Several authors [e.g. 5, 19] expect that the constitution of maps of assemblages that are stable over time will offer the possibility of anticipating the composition of catches of the corresponding fishing fleet. In the Gulf of Lions, a recent work on the trawler fleet in Sète allowed a formal characterization of several fishing strategies according to specific composition of landings and some technical features of the ships (power, length, age) [44]. Nevertheless, spatial dimension was not taken into account by these authors because no information was available on the fishing areas (absence of $\log$-book). In this context, comparative analysis 


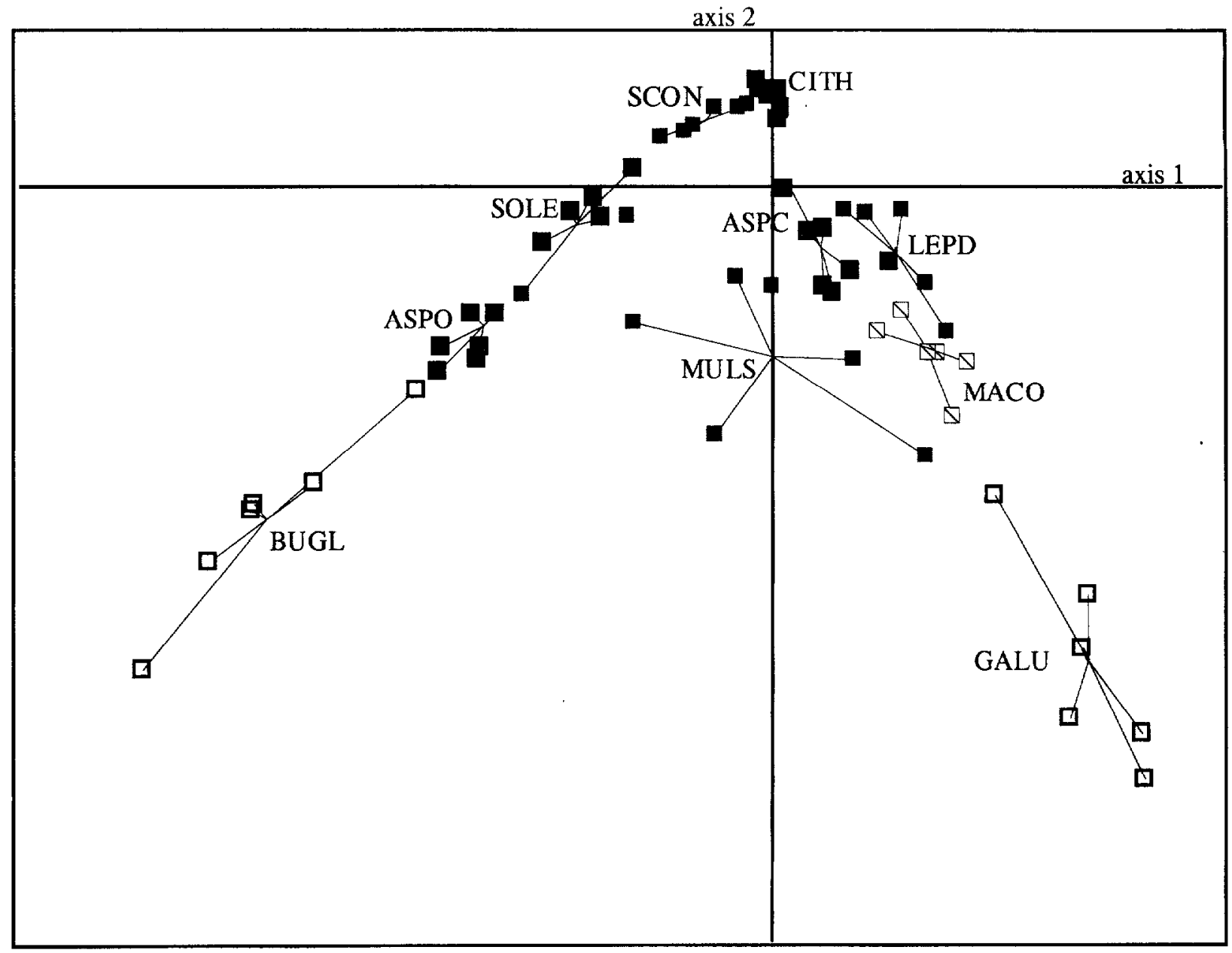

Figure 8. Detail of the projection of the trajectories of some characteristic species on the first factorial plane of STATIS compromise.

between the maps of assemblages obtain in the present work and commercial landings would constitute a first basis for monitoring the spatial organization of the trawling fleet in this region.

In addition, the perception of the stability or the variability in time of resources is often used to assess the reaction of communities to disturbances $[38,39]$. Gomes et al. [22] show that the distribution of demersal assemblages to the north-east of Newfoundland remained relatively stable between 1978 and 1987 , before undergoing a period of major changes that they associate with the intensity of fishing activities, but also with the general effect of the environment. In the Gulf of Lions, the impact of the fishing effort on the fishery resources has incrcased appreciably over the past four decades [33]. The effect of this increase of fishing pressure has recently been demonstrated at the scale of the Gulf with regard to the disappearence of numerous Squalidae [1]. Nevertheless, for the shorter period of our study, because of the diversification of a major part of the activity of trawlers to pelagic fishes (sardine and anchovy), it is difficult to quantify accurately the changes in fishing pressure on all the demersal species studied. The analysis of the impact of fishing on the spatial organization of the demersal assemblages would therefore require a better knowledge of changes in fleet strategies. This will constitute a next stage of our analysis of the demersal fisheries system in the Gulf of Lions.

In conclusion, the STATIS-Correspondence analysis has provided an accurate and reproductible representation of the stable part and the variable part of the spatial organization of demersal assemblages in the Gulf of Lions. Since it allows analysis of the reproducibility of multispecies spatial structures, this multitable technique offers a relevant basis of knowledge for the multispecies management. Finally, its application goes far beyond the field of fishery ecology to extend to a range of fields of community ecology. In particular, this technique should contribute to a better understanding of the reaction of marine communities to anthropic and natural disturbances. 


\section{Acknowledgments}

This work was supported by IFREMER and was included in the 'Programme de la Dynamique de la Biodiversité et Envirnnnement', French part of the 'Biodiversitas' international programme. We wish to thank the members of the Fisheries laboratory of IFREMER-Sète which conducted the CHALIST surveys. We also gratefully acknowledge F. Laloë, M. Simier, R. Sabatier and anonymous referees for their constructive comments.

\section{REFERENCES}

[1] Aldebert Y., Demersal resources of the Gulf of Lions (Northwestern Mediterranean). Impact of exploitation on fish diversity, Vie Milieu (1998) (in press).

[2] Amanieu A., Guelorget O., Nouguier-Soule J., Analyse de la diversité de la macrofaune benthique d'une lagune littorale Méditerranéenne, Vie Milieu 31 (1981) 303312.

[3] Benzecri J.P., Coll. L'analyse des données. II L'analyse des correspondances, Bordas, Paris, 1973, $620 \mathrm{p}$.

[4] Biagi F., De Ranieri S., Mori M., Sartor P., Sbrana M., Preliminary analysis of demersal fish assemblages in the northern Tyrrhenian sea, Nova Thalassia 10 (1989) 391-398.

[5] Bianchi G., Demersal assemblages of the continental shelf and slope edge between the gulf of Tehuantepec (Mexico) and the gulf of Papagayo (Coasta Rica), Mar. Ecol. Prog. Ser 73 (1991) 121-140.

[6] Bianchi G., Demersal assemblages of the continental shelf and upper slope of Angola, Mar. Ecol. Prog. Ser. 81 (1992) 101-120.

[7] Campillo A., Aldebert Y., Bigot J.L., Liorzou B., Données sur la distribution des principales espèces commerciales du golfe du Lion, IFREMER DRV89.041-RH-Sète, 1989,137 p.

[8] Centofanti M., Chessel D., Dolédec S., Stabilité d'une structure spatiale et compromis d'une analyse statistique multi-tableaux : Application à la physico-chimie d'un lac réservoir, Rev. Sci. Eau 2 (1989) 71-93.

[9] Chessel D., Hanafi M., Analyses de la co-inertie de K- nuages de points, Rev. Stat. Appl. 44 (1996) 35-60.

[10] Christie W.J., Spangler G.R., Loftus K.H., Hartman W.L., Colby P.J., Ross M.A., Talhem D.R., A perspective on great lakes fish community rehabilitation, Can. J. Aquat. Fish. Sci. 44 (suppl. 2) (1987) 486-499.

[11] Colcovocoresse J.A., Musick J.A., Species association and community composition of middle Atlantic bight continental shelf demersal fishes, Fish. Bull. 82 (1984) 295-313.

[12] Escoffier B., Pagès J., Multiple factor analysis (AFMULT package), Comput. Stat. Data Anal. 18 (1994) 121-140.

[13] Escoufier Y., Le traitement des variables vectorielles, Biometrics 29 (1973) 750-760.

[14] Escoufier Y., L'analyse conjointe de plusieurs matrices de données, in: Jolivet E. (ed.), Biométrie et temps, Société Française de Biométrie, Paris, 1980, pp. 59-76.

[15] Escoufier Y., L'analyse des tableaux de contingence simples et multiples, Metron 40 (1982) 53-77.
[16] FAO Code de conduite pour une pêche responsable, FAO, Rome, Italie, 1995, 46 p.

[17] Fujita T., Tadashi I., Ishito Y., Depht-gradient structure on the demersal fish community on the continental shelf and slope off Sendai Bay, Japan, Mar. Ecol. Prog. Ser. 118 (1995) 13-23.

[18] Gabriel W.L., Persistence of demersal fish assemblages between cape Hatteras and Nova Scotia, northwest Atlantic, J. Northw. Atl. Fish. Sci. 14 (1992) 29-46.

[19] Gabriel W.L., Tyler A.V., Preliminary analysis of Pacific coast demersal fish assemblages, Mar. Fish. Rev. (1980) 83-88.

[20] Gaertner J.C., Organisation des assemblages démersaux dans le golfe du Lion : structures spatiales et stabilité temporelle, Thèse dr. Univ. Aix-Marseille II, 1997, $139 \mathrm{p}$.

[21] Gomes M.C., Haedrich R.L., Rice J.C., Biogeography of goundfish assemblages on the Grand bank, J. Northw. Atl. Fish. Sci. 14 (1992) 13-27.

[22] Gomes M.C., Haedrich R.L., Villagarcia M.G., Spatial and temporal changes in the groundfish assemblages on the North-east Newfoundland/ Labrador shelf, northwest Atlantic, 1978-1991, Fish. Oceanogr. 4 (1995) 85101 .

[23] Goodall D.W., Objective methods for the classification of vegetation. III. An essay in the use of factor analysis, Austr. J. Bot. 2 (1954) 304-324,

[24] Gordon J.M., Bergstad O.A., Species composition of demersal fish in the Rockall Trough, North Eastern Atlantic, as determined by different travels, J. Mar. Biol. Assoc. UK. 72 (1992) 213-230.

[25] Hill M.O., Reciprocal averaging : an eigenvector method of ordination, J. Econ. 61 (1973) 237-249.

[26] Kroonenberg P.M., Three-mode principal component analysis, DSWO Press, 1983, $398 \mathrm{p}$.

[27] Lavit C., Escoufier Y., Sabatier R., Traissac P., The ACT (Statis method), Comput. Stat. Data Anal. 18 (1994) 97-119.

[28] Liorzou B., Campillo A., Bigot J.L., Estimation de l'abondance relative de Lophius budegassa du golfe du Lion à partir des campagnes de chalıtage (1983-1987), Bull. Soc. Zool. France 114 (1989) 101-112.

[29] Mahon R., Grounfish assemblages on the Scotian shelf, in: Mahon R. (ed.). Toward the inclusion of fishery interactions in management advice, Can. Tech. Rep. Fish. Aquat. Sci. 1347 (1985) 153-162.

[30] Mahon R., Smith R.W., Demersal fish assemblages on the Scotian shelf, northwest Atlantic: spatial distribution and persistence, Can. J. Aquat. Fish. Sci. 46 (1989) 134-152. 
[31] Manly B.F.J., Randomization and Monte Carlo methods in biology. Chapman and Hall, London, 1991, 281p.

[32] Maurin C., Ecologie ichthyologique des fonds chalutables atlantiques (de la baie ibéro-marocaine à la Mauritanie) et de la Méditerranée occidentale, Rev. Trav. Inst. Pêches marit. 32 (1968) 5-147.

[33] Meuriot E., Dremière P.Y., Capelle J., Le chalutage en Méditerranée : le port de Sète, Rapp. Econ. Jurid. IFREMER 3, 1987, 147 p.

[34] Miller M.J., Species assemblages of leptocephali in the Sargasso sea and Florida current, Mar. Ecol. Prog. Ser. 121 (1995) 11-26.

[35] Murawski S.A., Lange A.M., Sissenwine M.P., Mayo R.K., Definition and analysis of multispecies otter-trawl fisheries off the northeast coast of the United States. J. Cons. Int. Explor. Mer 41 (1983) 13-27.

[36] Overholtz W.J., Tyler A.V., Long-term responses of the demersal fish assemblages of Georges Bank, Fish. Bull. 83 (1985) 507-520.

[37] Perry R.I., Stocker M., Fargo J., Environmental effects on the distribution of groundfish in Hecate Strait, British Columbia, Can. I. Fish. Aquat. Sci. 51 (1994) 1401-1409.

[38] Pimm S.L., The complexity and stability of ecosystems, Nature 307 (1984) 321-326.

[39] Pimm S.L., Hyman J.B., Ecological stability in the context of multispecies fisheries, Can. J. Fish. Aquat. Sci. 44 (suppl. 2) (1987) 84-94.

[40] Rakocinski C.F., Baltz D.M., Fleeger J.W., Correspondence between environmental gradients and the community structure of marsh-edge fishes in a Louisiana estuary, Mar. Ecol. Prog. Ser 80 (1992) 135-148.

[41] Robert P., Escoufier Y., A unifying tool for linear multivariate statistical methods: the RV coefficient, Appl. Stat. 25 (1976) 257-265.

\section{APPENDIX}

Let

$I=$ total number of rows of the table (i.e. total number of sampled stations during the six surveys)

$J=$ number of columns (i.e. number of species considered)

$K=$ number of subtables (i.e. number of surveys)

$I_{k}=$ number of rows of the subtable $k$ (i.e. number of stations sampled during the survey $k$ )

For $1 \leq i \leq I$, then $b(i)=k$ when the row $i$ belongs to the subtable $k$

$\mathbf{X}=\left[\mathrm{x}_{i i}\right]_{1 \leq i \leq l, 1<j \leq J}$ is the initial table (composed by $K$ subtables) which contains only positives or equal to zero values.

The weight of the column $j$ is given by $p_{j}=\frac{x_{j}}{x_{\text {.. }}}$ with

$$
x_{j}=\sum_{1 \leq i \leq 1} x_{i j} \text { and } x_{. .}=\sum_{1 \leq j \leq J} x_{j}
$$

The diagonal matrix of column weights is

$$
D_{J}=\operatorname{Diag}\left(p_{.1}, p_{.2}, \ldots ., p_{. j}\right) \text {. }
$$

[42] Roel B.A., Demersal communities off the west coast of south Africa, S. Afr. J. Mar. Sci. 5 (1987) 575-584.

[43] Romesburg, H.C., Exploring, confirming and randomization tests, Comp. Geogr. 11 (1985) 19-37.

[44] Taquet M., Gaertner J.C., Bertrand J., Typologie de la flottille chalutière de Sète : formalisation par une méthode de segmentation, Aquat. Living Resour. 10 (1997) 137-148.

[45] Ter Braak C.J.F., Canonical correspondence analysis: a new eigenvector technique for multivariate direct gradient analysis, Ecology 67 (1986) 1167- 1179.

[46] Ter Braak C.J.F., The analysis of vegetation-environment relationships by canonical correspondence analysis, Vegetatio 69 (1987) 69-77.

[47] Thioulouse J., Chessel D., A method for reciprocal scaling of species tolerance and sample diversity, Ecology 73 (1992) 670-680.

[48] Thioulouse J., Dolédec S., Chessel D., Olivier J.M., ADE software: multivariate analysis and graphical display of environmental data, Proc. 4th Int. Software exhibition for environmental science and engineering, 1995, pp. 57-62.

[49] Tyler A.V., Gabriel W.L., Overholtz W.J., Adaptative management based on structure of fish assemblages of northern continental shelves, Can. Spec. Publ. Fish. 59 (1982) 149-156.

[50] Wantiez L., Les poissons des fonds meubles du lagon nord et de la baie de Saint Vincent de Nouvelle Calédonie. Thèse dr. Univ. Aix-Marseille II, 1993, 44 p.

[51] Weinberg K.L., Rockfish assemblages of the middle shelf and upper slope off Oregon and Washington, Fish. Bull. 92 (1994) 620-632.

The weight of the row $i$ of the subtable $k$ is given by

$$
p_{i .}=\sum_{1 \leq j \leq j} p_{. j} p_{i / j}
$$

with

$$
p_{i / j}=\frac{x_{i j}}{x_{. j}^{b(i)}} \text { and } x_{. j}^{k}=\sum_{b(i)=k} x_{i j}
$$

The diagonal matrix of row weights of the subtable $k$ is $\mathrm{D}_{l k}=\operatorname{Diag}\left(p_{i}\right)$

The diagonal matrix of row weights of the entire table is $\mathrm{D}_{l}=\operatorname{Diag}\left(p_{l}, \ldots, p_{i,}, \ldots, p_{l .}\right)$

The sum of the row weigts of a subtable equal 1 , those of the table equal $K$.

The table is centred as in a Correspondence Analysis (see [15]) by $\mathrm{y}_{i j}=\left(p_{i j} / p_{i}\right)-1$

The subtable is defined by

$$
\mathrm{Y}_{k}=\left[\mathrm{y}_{i j}\right]_{b(i)=k, 1 \leq j \leq J}
$$

It provides the statistical triplet $\left(\mathrm{Y}_{k}, \mathrm{D}_{J}, \mathrm{D}_{l k}\right)$ which is a triplet of a Correspondence Analysis. 